Jurnal Ilmu Pengetahuan dan Pengembangan Masyarakat Islam ISSN: 2085-8833, E-ISSN:2797-6963 | Vol. 15, No. 2, Oktober, 2021, pp. $93-101$ http: http://ejournal.uin-suska.ac.id/index.php/Menara/index

\title{
Peningkatan Ekonomi Masyarakat Pulau Kecil Melalui Pemanfaatan Dan Pengolahan Biji Karet Dengan Teknologi Wafer Sebagai Pakan Ternak Kambing
}

\author{
Dewi Ananda Mucra, Triani Adelina, Anwar Efendi Harahap, Jepri Juliantoni \\ 123 Universitas Islam Negeri Sultan Syarif Kasim Riau \\ E-mail: harahapa258@gmail.com
}

\begin{abstract}
Abstrak
Pulau Busuk adalah pulau kecil yang terletak di Kabupatensssss Kuantan Singingi Provinsi Riau. Sumber daya sangat potensial yang berada di Pulau ini adalah perkebunan karet. Pengabdian ini bertujuan untuk memanfaatkan dan mengolah biji karet dengan teknologi wafer sebagai pakan ternak kambing sebagai usaha meningkatkan kesejahteraan masyarakat. Metode pengabdian adalah metode Community Based Research (CBR) yaitu metode dimana masyarakat turut andil dalam proses penelitian dan pengabdian ini. Hasil menunjukkan bahwa kegiatan pengabdian menghasilkan 80-90\% umpan balik dari masyarakat, walaupun sebagian besar masyarakat memiliki tingkat pendidikan yang rendah tetapi masih mudah memahami materi, kandungan nutrisi wafer yang dihasilkan antara perlakuan yaitu protein kasar 10,02-11,40\%, serat kasar 21,00-21,55 dan lemak kasar 4,36-6,92. Kesimpulan pengabdian ini adalah wafer dengan penambahan limbah biji karet hingga level $21 \%$ dalam ransum dapat dijadikan sebagai pakan ternak kambing dengan model pengabdian community based research (CBR) yang merupakan model efektif untuk memotivasi peternak dalam meningkatkan perkembangan dan pertumbuhan kambing secara maksimal, sehingga nilai jual ternak kambing juga tinggi dan berimplikasi terhadap peningkatan kesejahteraan masyarakat
\end{abstract}

Kata Kunci: Pengabdian, Pulau Busuk, Pakan, Wafer, Kambing

\section{Abstract}

Busuk Island is a small island located in Kuantan Singingi Regency, Riau Province. Potential resource on this island is rubber plantations. This service aims to utilize and process rubber seeds with wafer technology as goat fodder in an effort to improve community welfare. The service method is a Community Based Research (CBR) method is a method in which the community participates in this research and service process. The results show that community service activities produce 80 - 90\% feedback from the community, although most people have a low level of education but it is still easy to understand the material, wafer nutrient content produced between treatments namely crude protein $10.02-11.40 \%$, crude fiber $21.00-21.55 \%$ and crude fat $4.36-6.92 \%$. The conclusion of this service is that wafers with the addition of rubber seed waste to the level of $21 \%$ in the ration can be used as goat fodder with a community based research (CBR) service model which is an effective model to motivate farmers to increase the development and growth of goats to the maximum, so that the sale value goat livestock are also high and have implications for improving the welfare of the community

Keywords: Devotion, Busuk Island, Feed, Wafers, Goats 


\section{Pendahuluan}

Pulau Busuk adalah pulau kecil yang terletak di Kecamatan Inuman Kabupaten Kuantan Singingi Provinsi Riau. Data menunujukkan bahwa pulau busuk merupakan kecamatan yang garis kemiskinan (Pemerintah Kabupaten Kuantan Singingi, 2011). Adapun tujuan pengelolaan pulau-pulau kecil terluar selain untuk menjaga pertahanan dan pemnafatan sumberdaya alam nasional, juga diharapkan dapat mengatasi ancaman keamanan yang meliputi transnasional. Pengembangan pulau-pulau kecil memiliki karakteristik khusus karena pulau-pulau ini pada umunya memiliki sumberdaya alam, aspek lingkungan, dan budaya yang khas. Beberapa karakteristik ekosistem pulau-pulau kecil yang dapat merupakan kendala bagi pembangunan adalah ukuran yang kecil dan terisolasi, sehingga penyediaan sarana dan prasarana menjadi sangat mahal, dan sumber daya yang andal menjadi langka (Undang Undang Republik Indonesia Nomor 27 Tahun 2007)

Sumber daya sangat potensial yang berada di Pulau Busuk Kecamatan Inuman Kabupaten Kuantan Singingi adalah perkebunan karet. Limbah perkebunan karet merupakan salah satu pakan alternatif yang mudah didapat di daerah Provinsi Riau. Berdasarkan data statistik Dinas Perkebunan Provinsi Riau Tahun 2013, luas perkebunan karet di daerah Riau mencapai 505.264 ha. Kabupaten Kuantan Singingi merupakan kabupaten yang mempunyai areal karet yang paling luas di Provinsi Riau, yaitu $146.474 \mathrm{Ha}$ atau 30 persen dari luas total areal perkebunan karet di Provinsi Riau. Setiap hektar perkebunan karet ditanami 450 sampai 600 pohon karet. Setiap tanaman karet mampu menghasilkan 5.000 sampai 10.000 biji karet atau 25 sampai $50 \mathrm{~kg}$ biji karet per tahun (Dinas Perkebunan Provinsi Riau, 2013). Dengan demikian jumlah biji karet yang dihasilkan di Kabupaten Kuantan Singingi adalah 1.708.976,25 - 4.557.270 ton/tahun.

Marimpun (2003) menyatakan bahwa kandungan nutrisi tepung biji karet memiliki kandungan protein 21,82\%, energi metabolis $6179 \mathrm{kkal} / \mathrm{kg}$, lemak kasar $45,22 \%$ dan serat kasar 6,05\%. Untuk memperbaiki nilai nutrisi dari tepung biji karet perlu dilakukan pengolahan wafer dan diharapkan dapat menjaga keseimbangan ketersediaan bahan hijauan pakan dimana proses pembuatannya mengalami pemadatan dengan tekanan $12 \mathrm{~kg} / \mathrm{cm}^{2}$ dan pemanasan dalam suhu $120^{\circ} \mathrm{C}$ selama 10 menit. Produksi biji karet yang sangat tinggi ini, apabila tidak dimanfaatkan dengan baik akan mengalami pencemaran lingkungan, padahal biji karet ini tersebut masih dapat dimanfaatkan menjadi pakan ternak terutama ternak kambing sehingga kelompok petani yang ada di pulau tersebut tidak mengalami kesulitan untuk memenuhi kebutuhan makanan ternak tersebut.

Berdasarkan kondisi tersebut telah dilaksanakan kegiatan pengabdian dengan kelompok masyarakat Pulau Busuk tentang pengembangan ternak Kambing dengan penggunaan dan pengolahan pakan wafer menggunakan bahan pakan lokal yaitu tepung biji karet

\section{Metode}

Pengabdian ini telah dilaksanakan selama 5 bulan dimulai bulan Juli sampai dengan November 2019. Pembuatan wafer dan analisis fisik dilakukan di Desa Pulau Busuk Kecamatan Inuman Kabupaten Kuantan Singingi Provinsi Riau sedangkan Analisa Nutrisi Wafer dilaksanakan di Laboratorium Nutrisi dan Teknologi Pakan Fakultas Pertanian dan Peternakan Universitas Islam Negeri Sultan Syarif Kasim Riau 


\section{Alasan Memilih Subyek Dampingan}

Adapun alasan memilih Pulau kecil yang ada di Kabupaten Kuantan Singingi sebagai subyek dampingan didasarkan pada analisis situasi sebagai berikut:

1. Pulau Busuk yang ada di Kabupaten Kuantan Singingi termasuk pulau pulau kecil (Undang-Undang No. 27 Tahun 2007) yang perlu mendapat perhatian untuk pengembangan kesejahteraan masyarakat tersebut

2. Belum optimalnya pemanfaatan limbah biji karet yang sangat melimpah di Pulau Busuk Kabupaten Kuantan Singingi, apabila limbah biji karet ini tidak dapat dimanfaatkan secara maksimal maka akan mengakibatkan pencemaran lingkungan

3. Pola Beternak kambing pada kelompok masyarakat tersebut masih bersifat ekstensif sehingga perlu ada perubahan pola beternak kambing ke semi intensif dan intensif

4. Belum memahami pemanfaatan bahan tepung biji karet dengan teknologi pengolahan pakan wafer sebagai ransum kambing

\section{Kondisi Subyek Dampingan Saat Ini}

Desa Pulau Busuk adalah salah satu desa dari sebelas desa yang terdapat di Kecamatan Inuman Kabupaten Kuantan Singingi di Provinsi Riau. Desa Pulau Busuk terdiri dari 12 RT, orbitase (jarak) antara Desa Pulau Busuk dengan ibu Kota Kecamatan Inuman $5 \mathrm{Km}$ dan jarak antara Desa Pulau Busuk dengan Ibu Kota Kabupaten Kuantan Singingi sekitar $47 \mathrm{Km}$, sedangkan jarak Desa Pulau Busuk dengan Ibu Kota Provinsi (Pekanbaru) sekitar 215 Km. Desa Pulau Busuk terletak diantara Sungai Batang Kuantan dan Jalan Raya (jalan lintas), sehingga daerah tersebut ada yang berawa-rawa dan ada juga daratan. Desa Pulau Busuk memiliki dua musim, yaitu musim panas dan musim hujan. Dengan demikian, alat transportasi yang bisa digunakan dengan jalan darat dan juga ditempuh dengan transportasi air. Melalui transportasi air (sungai) biasanya masyarakat Desa Pulau Busuk memakainya untuk mengunjungi Desa Seberang Pulau Busuk. Bentuk permukaan tanah Desa Pulau Busuk adalah rawa-rawa dan daratan, maka daerah rawa-rawa bisa mereka pergunakan untuk sawah (menanam padi), sedangkan daeraah daratan yang kering mereka gunakan untuk pemukiman dan mereka pakai untuk berladang (menanam sayuran, palawija, karet, kelapa, dan tanaman lainnya (Bappeda Kabupaten Kuantan Singingi, 2011)

Masyarakat Desa Pulau Busuk Kecamatan Inuman Kabupaten Kuantan singingi masih memiliki rasa sosial yang sangat tinggi, rasa sosial yang terbentuk antara satu sama yang lainnya saling memerlukan dan juga merasa seperasaan, yag terlihat nyata dalam kehidupan sehari-hari seperti gotong royong, bermusyawarah dalam menyelesaikan satu masalah yang terjadi dan banyak aktivitas yang lainnya yang mereka lakukan bersama-sama

\section{Kondisi Dampingan Yang Diharapkan}

Adapun kondisi dampingan yang diharapkan lebih spesifik dari kegiatan pengabdian masyarakat ini adalah :

- Terbentuknya pola pemikiran yang baru bahwa usaha peternakan bukan hanya merupakan usaha sambilan tetapi dapat dijadikan sebagai usaha utama, apalagi dengan merosotnya harga jual karet di pasaran sehingga dapat berimplikasi terhadap penurunan pendapatan masyarakat 
- Terbentuknya kelompok tani andalan dengan pendampingan tim pengabdi dari perguruan tinggi sehingga lebih memahami cara beternak kambing, pengolahan limbah biji karet, pemasaran pakan wafer dan pemasaran ternak kambing

- Terbentuknya koperasi petani di Lokasi pengabdian yang beranggotakan seluruh kelompok petani sehingga lebih mudah mengelola usaha beternak kambing dan aspek pemasaran

\section{Metode Kegiatan Pengabdian}

Metode kegiatan pengabdian yaitu : Community Based Research (CBR) yang dilakukan oleh tim pengabdi. Pada Strategi ini dilakukan kegiatan pada saat pendampingan masyarakat dengan dua Tahap yaitu

Tahap 1. Kegiatan Sosialisasi dan penyampaian materi pendampingan yang bertujuan antara lain :

- Memotivasi untuk merubah sistem pemeliharaan kambing yang sebelumnya menggunakan sistem ekstensif (dilepas sepanjang hari) untuk selanjutnya menjadi sistem pemeliharaan semiintensif (dilepas dan dikandangkan)

- Memotivasi kelompok tani di Desa Pulau Busuk agar mampu membuat produk pakan wafer secara mandiri dengan adanya model kemasaan

Tahap 2. Penelitian Bersama dengan Kelompok masyarakat. Kegiatan penelitian dilakukan antara lain

- Melakukan pelatihan bersama dengan komunitas petani tentang pembuatan pakan wafer berbahan tepung Biji karet.

- Melakukan Pelatihan formulasi ransum kambing dengan komunitas petani. Adapun Formulasi ransum wafer yang ditambahkan tepung biji karet terhadap ternak kambing. Adapun perlakuan untuk semua tahap dalam pengabdian ini adalah:

A1 : Formulasi Ransum Kambing Tanpa Penambahan Tepung Biji Karet

A2 : Formulasi Ransum dengan penambahan 7 \% Tepung Biji Karet

A3 : Formulasi Ransum dengan penambahan $14 \%$ Tepung Biji Karet

A4 : Formulasi Ransum dengan penambahan $21 \%$ Tepung Biji Karet

Selanjutnya pakan wafer yang yang telah dihasilkan dilakukan analisis protein kasar (\%), serat kasar (\%) dan lemak kasar (\%)

\section{Hasil dan Pembahasan}

\section{Gambaran Lokasi Kegiatan}

Untuk mencapai lokasi penelitian yang terdapat di Pulau Busuk Kecamatan Inuman Kabupaten Kuantan Singingi, tim pengabdi harus melewati luasnya perkebunan karet. Mayoritas wilayah ini ditanami karet sehingga sangat berpotensi sekali untuk dijadikan pakan ternak. Limbah biji karet yang dihasilkan hanya dibuang saja tanpa ada proses pengolahan lebih lanjut. Berikut adalah kondisi lokasi kegiatan di Daerah. 


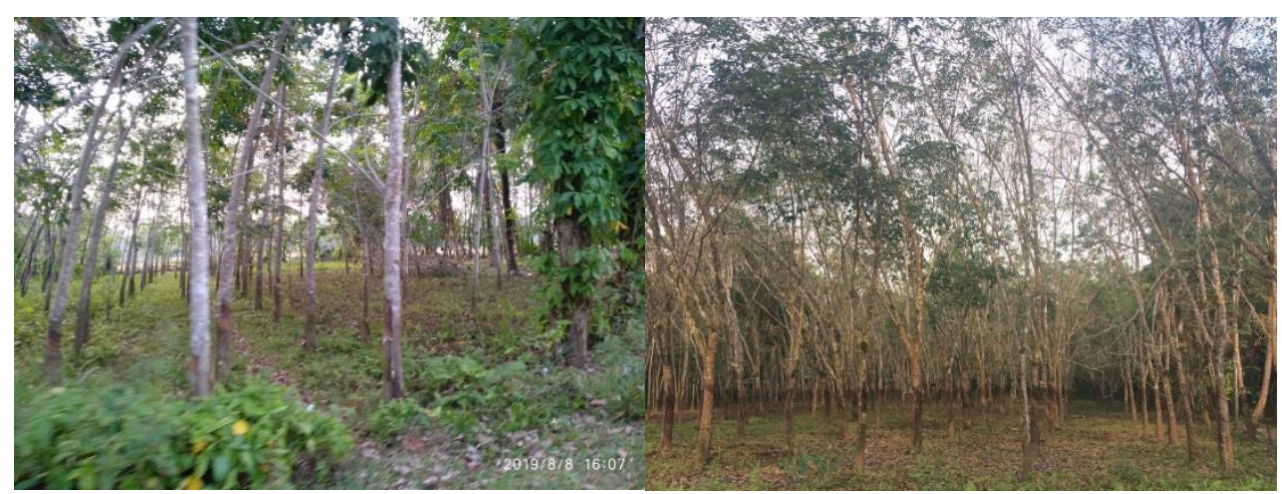

Gambar 1. Kondisi Wilayah Pengabdian

\section{Kondisi Pengolahan Tepung Biji Karet}

Produk komersial utama biji karet adalah minyak dan hasil sampingannya berupa bungkil biji karet. Hampir seluruh bagian biji karet dapat dimanfaatkan. Minyaknya dapat dimanfaatkan dalam industri cat, sabun dan pernis, bungkilnya untuk pakan ternak dan tempurungnya dapat digunakan untuk pembuatan karbon aktif. Biji karet yang dihasilkan dari perkebunan, selanjutnya dilakukan proses pengolahan. Pengolahan dilakukan dengan cara fisik yaitu pemecahan, pencacahan, penjemuran dan perebusan sehingga layak digunakan sebagai pakan ternak kambing. Adapun diagram pengolahan tepung biji karet dapat dilihat pada Gambar ini

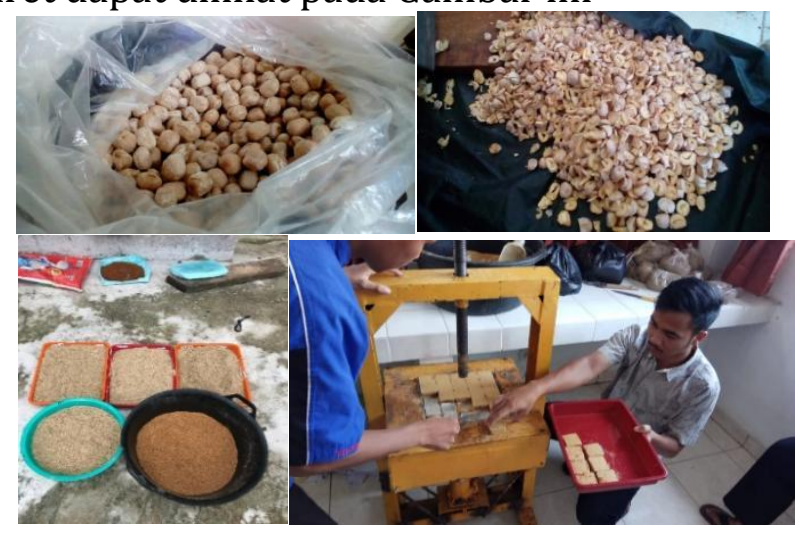

Gambar 2. Kondisi Pengolahan Biji Karet Menjadi Wafer

\section{Kondisi Sosial Masyarakat di Wilayah Kajian}

Kondisi sosial masyarakat di Pulau busuk mayoritas berumur 20 - 40 tahun dengan pendidikan antara SD dan SMP serta memiliki pekerjaan sebagai petani karet dan hanya sebagian kecil yang memiliki pekerjaan sebagai beternak. Beternak hanya sebagai usaha sambilan saja untuk menambah pendapatan masyarakat di Pulau Busuk dengan pengalaman beternak antara 2 - 5 tahun. Mayoritas usaha bertani karet dilakukan oleh wanita sedangkan warga yang laki laki mayoritas bekerja sebagai buruh pabrik dan buruh bangunan.

Usaha beternak yang dilakukan masyarakat masih bersifat sangat tradisional dengan komiditi ternaknya adalah sapi bali. Kondisi beternak tradisional dilihat dari sistem pemeliharaan yang mayoritas dilepas di padang pegembalaan tanpa kontrol manajemen yang baik dan benar. Ada beberapa masyarakat yang sudah memelihara sapi di dalam kandang, tetapi pemeliharaan kandang hanya malam saja, begitu siang hingga sore hari, pemeliharaan juga tetap dilepas di lapangan. Kandang yang digunakan juga 
sangat tradisional dan tidak memenuhi standard antara lain konstruksi kandang yang tidak memenuhi syarat, drainase kandang yang sangat jelek dan frekuensi pembersihan kandang dan saluran pembuangan kotoran ternak yang tidak terkontrol.

Selanjutnya untuk pengaturan pakan juga tidak terkelola dengan baik, pakan untuk ternak sapi hanya diperoleh dari padang pengembalaan dengan sistem ternak yang dilepas, sehingga tidak jelas jenis, umur dan kualitas pakan yang dikonsumsi ternak sapi tersebut. Mayoritas jenis pakan yang dikonsumsi ternak sapi adalah rumput lapang atau rumput liar yang ada di sekitar perkarangan rumah.

Pengembangan usaha peternakan sapi di lokasi hanya difokuskan sebagai usaha sambilan saja, artinya beternak sabagai tabungan untuk keperluan dan kebutuhan masyarakat dalam kondisi darurat contohnya untuk keperluan sekolah, kegiatan pesta dan lain lain. Kondisi ini yang mengakibatkan usaha beternak sapi hanya sebagai usaha tambahan tanpa pengelolaan manajamen peternakan yang baik.

\section{Kondisi Pelatihan Pembuatan Pakan Wafer}

Kegiatan pennelitian dilaksanakan pada Desa Pulau Busuk Kecamatan Inuman Kabupaten Kuantan Singingi memperoleh umpan balik atas pelaksanaan pengabdian yang telah dibuat. Kegiatan pengabdian menghasilkan 80 - $90 \%$ umpan balik dari masyarakat, walaupun sebagian besar masyarakat memiliki tingkat pendidikan yang rendah tetapi masih mudah memahami materi pelatihan yang disajikan oleh narasumber. Kegiatan pelatihan dimulai dengan presentasi narasumber yang berkaitan dengan pembuatan pakan wafer. Cakupan berbagai kegiatan untuk dapat memberikan pemahaman dalam meningkatkan pengetahuan masyarakat mengenai pembuatan dan pemanfaatan pakan wafer. Berdasarkan analisis bahwa kegiatan pelatihan memiliki faktor - faktor pendukung antara lain kemauan dan kerja keras masyarakat untuk belajar bagaimana cara membuat pakan wafer dengan baik dengan konsep ipteks yang terbarukan, sifat kebersamaan masyarakat koordinasi yang jelas antara masyarakat desa sehingga semua masyarakat mempunyai rasa memiliki pemahaman terhadap teknologi tersebut.

Dari Faktor-faktor pendukung kegiatan pelatihan tersebut maka dampak langsung yang dapat dirasakan masyarakat adalah menyediakan informasi tentang peluang investasi di bidang pengolahan pakan ternak yang sangat potensial, menyediakan informasi dan pengetahuan untuk mengembangkan usaha beternak terutama pengolahan pakan wafer terutama di masyarakat sedangkan dampak tidak langsung adalah model usaha pembuatan pakan wafer yang efisien dan berkesinambungan. Adapun kondisi saat pelatihan dapat dilihat pada Gambar berikut

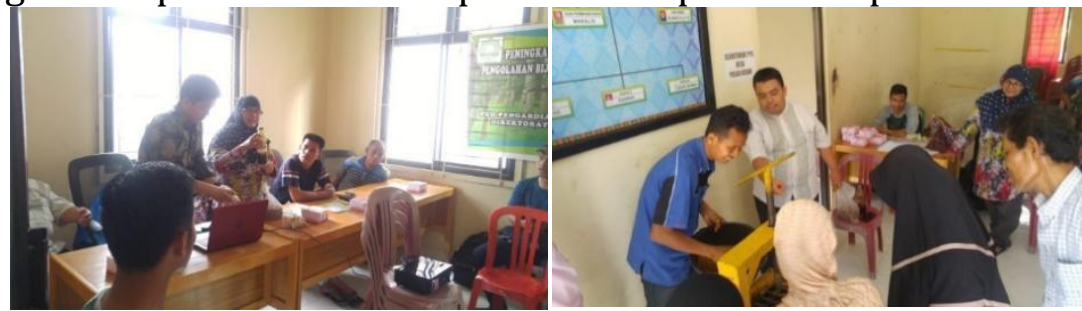

Gambar 3. Kondisi Saat Pelatihan di Pulau Busuk

\section{Kualias Fisik Pakan Wafer Kambing}

Prinsip pembuatan wafer mengikuti prinsip pembuatan papan partikel. Sifat partikel menurut Jayusmar (2000) dipengaruhi oleh jenis dan ukuran partikel, teknik 
pembuatan, jenis dan kondisi perekat distribusi partikel, kerapatan partikel, kadar air, dan pengerjaan lanjut papan partikel. Untuk lebih jelasnya wafer yang dihasilkan setiap perlakuan dapat dilihat pada Gambar dibawah ini.

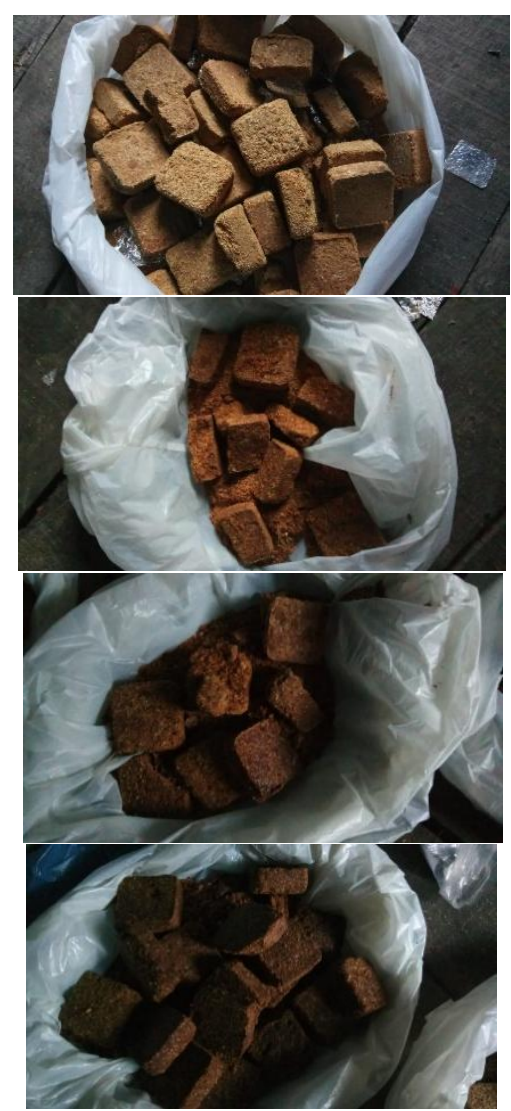

Gambar 4.Produk Wafer yang dihasilkan Setiap Perlakuan

\section{Kandungan Nutrisi Pakan Wafer}

\section{Protein Kasar}

Rataan kandungan protein kasar wafer dengan penambahan Biji Karet dengan level yang berbeda dapat dilihat pada Tabel 1 di bawah ini.

Tabel 1. Rataan Kandungan Protein Kasar wafer Biji Karet dengan level berbeda (\%)

\begin{tabular}{llc}
\hline \multicolumn{2}{c}{ Perlakuan Ransum } & Rataan \\
\hline & P0 & 11.40 \\
P1 & 10.17 \\
P2 & 10.47 \\
& P3 & 10.02 \\
\hline Keterangan : & P0 = Wafer Ransum dengan Biji Karet 0\%, P1 = Wafer Ransum dengan \\
& Biji Karet 7\%, P2 = Wafer Ransum Biji Karet 14\%, P3 = Wafer Ransum
\end{tabular}

Pada Tabel diatas menunjukkan terjadi penurunan kandungan protein kasar (\%) seiring dengan penambahan level dari tepung biji karet, hal ini kemungkinan disebabkan 
karena semakin tinggi penggunaan level biji karet maka penggunaan dari tepung jagung dalam formulasi ransum semakin berkurang sehingga berimplikasi penurunan kandungan protein pada setiap perlakuan. Perlakuan biji karet wafer ternyata dapat menurunkan kandungan protein kasar. Menurut Wizna, dkk., (2010), kandungan dari daging biji karet tanpa perlakuan mengandung protein kasar 19,20\%.

Rataan kandungan Serat kasar wafer dengan penambahan Biji Karet dengan level yang berbeda dapat dilihat pada Tabel 2 di bawah ini

Tabel 2. Rataan Kandungan Serat Kasar wafer Biji Karet dengan level berbeda (\%)

\begin{tabular}{cc}
\hline Perlakuan Ransum & Rataan \\
\hline P0 & 21.00 \\
P1 & 21.55 \\
P2 & 21.71 \\
P3 & 21.57 \\
\hline
\end{tabular}

Keterangan : $\quad$ P0 = Wafer Ransum dengan Biji Karet 0\%, P1 = Wafer Ransum dengan Biji Karet 7\%, P2 = Wafer Ransum Biji Karet 14\%, P3 = Wafer Ransum dengan Biji Karet $21 \%$

Pada Tabel diatas menunjukkan terjadi kenaikan kandungan serat kasar (\%) seiring dengan penambahan level dari tepung biji karet, hal ini menunjukkan bahwa Biji Karet merupakan bahan pakan yang tinggi sumber serat kasar sehingga semakin tinggi penggunaan level biji karet maka serat kasar yang dihasilkan juga semakin tinggi

\section{Lemak Kasar}

Rataan kandungan Lemak kasar wafer dengan penambahan biji karet dengan level yang berbeda dapat dilihat pada Tabel 3 di bawah ini Tabel 3. Rataan Kandungan Lemak Kasar wafer Biji Karet dengan level berbeda (\%)

\begin{tabular}{cc}
\hline Perlakuan Ransum & Rataan \\
\hline P0 & 4.36 \\
P1 & 4.58 \\
P2 & 6.08 \\
P3 & 6.92 \\
\hline
\end{tabular}

Keterangan : $\quad$ P0 $=$ Wafer Ransum dengan Biji Karet 0\%, P1 = Wafer Ransum dengan Biji Karet 7\%, P2 = Wafer Ransum Biji Karet 14\%, P3 = Wafer Ransum dengan Biji Karet $21 \%$

Pada Tabel diatas menunjukkan terjadi peningkatan kandungan lemak kasar (\%) seiring dengan penambahan level dari tepung biji karet, hal ini kemungkinan disebabkan karena semakin tinggi penggunaan level biji karet maka kandungan lemak dalam formulasi ransum juga semakin bertambah akibat pemberian biji karet yang merupakan sumber lemak. Proses wafer menyebabkan terjadi penurunan lemak kasar. Hal ini senada yang disampaikan Novita $d k k$., 2019 bahwa kandungan biji karet mengandung lemak kasar 47,20\%, 


\section{Simpulan}

1. Model Pengabdian dengan metode Community Based Research (CBR) merupakan model yang efektif untuk memotivasi peternak dalam merubah sistem pemeliharaan kambing yang sebelumnya menggunakan sistem ekstensif (dilepas sepanjang hari) selanjutnya menjadi sistem pemeliharaan semiintensif (dilepas dan dikandangkan) sehingga menunjukkan bahwa peternak turut andil dalam proses penelitian dan pengabdian ini

2. Seluruh peserta pengabdian masyarakat Pulau Busuk mengikuti pelatihan secara serius dan semangat ditandai dengan banyak umpan balik atas kegiatan Pengabdian Masyarakat tersebut.

3. Pengabdian ini terbentuknya usaha peternakan kolektif yang mandiri dan berorientasi bisnis profit melalui pendampingan, pengawalan, aplikasi teknologi dan informasi, transfer ilmu pengetahuan.

4. Penggunaan limbah biji karet hingga level $21 \%$ dalam formulasi wafer ransum Kambing masih menghasilkan kualitas nutrisi yang baik dilihat dari protein kasar (\%), serat kasar (\%) dan lemak kasar (\%) sehingga berpotensi dijadikan pakan ternak kambing untuk meningkatkan pertambahan bobot badan dan memiliki nilai jual tinggi sehingga berimplikasi pada peningkatan pendapatan dan kesejehteraan masyarakat

\section{Saran}

1. Wafer ransum dengan penambahan limbah biji karet hingga level $21 \%$ dapat dijadikan sebagai pakan ternak kambing

2. Perlu adanya perhatian dari pemerintah daerah dalam mengembangkan teknologi pengolahan pakan wafer dengan memanfaatkan potensi limbah pertanian dan perkebunan yang ada di daerah

\section{Referensi}

Badan Perencanaan Pembangunan Daerah. (2011). Strategi Penanggulangan Kemiskinan Kabupaten Kuantan Singingi.

Dinas Perkebunan Provinsi Riau, (2013)

Marimpun. (2003). Pengaruh Penggunaan Tepung Biji Karet (Havea brassiliensis) dalam Ransum terhadap Produksi Telur Burung Puyuh (Coturnix-coturnix japonica) Umur 1-6 Minggu. Skripsi. Jurusan Peternakan, Fakultas Pertanian Universitas Sumatera Utara. Medan.

Novita, R., Herlina B dan Permata, L. (2019). Level Pemberian Tepung Biji Karet Terhadap Produksi dan Bobot Telur Burung Puyuh (Coturnix coturnix Japonica. Jurnal Biologi. 1 (2): 87 - 94

Pemerintah Kabupaten Kuantan Singingi, (2011)

Undang Undang Republik Indonesia Nomor 27 Tahun (2007)

Wizna, Mirnawati, J, Novirman, Yenti dan Zuryani. (2010). Pemanfaatan Produk Fermentasi Biji Karet (Havea Brasiliensis) dengan Rhizopus Oligosporus dalam Ransum Ayam Broiler. Seminar Nasional Peternakan dan Veteriner 1. Bogor: Pusat Penelitian Peternakan, Badan Penelitian Dan Pengembangan Pertanian. 